\title{
Kanuka Oil
}

National Cancer Institute

\section{Source}

National Cancer Institute. Kanuka Oil. NCI Thesaurus. Code C107319.

The essential oil of Leptospermum (Kunzea) ericoides. Kanuka oil has anti-fung al and anti-inflammatory properties and is used in skincare preparations. 